\title{
The laboratory diagnosis of hepatitis B virus
}

\author{
Mel Krajden MD, Gail McNabb BSc ART, Martin Petric PhD
}

\begin{abstract}
M Krajden, G McNabb, M Petric. The laboratory diagnosis of hepatitis B virus. Can J Infect Dis Med Microbiol 2005;16(2):65-72.
\end{abstract}

Hepatitis B virus (HBV) chronically infects approximately 250,000 Canadians and 350 million people worldwide. Without intervention, approximately $15 \%$ to $40 \%$ of chronically infected individuals will eventually develop cirrhosis, end-stage liver disease or hepatocellular carcinoma, or require liver transplantation. The availability and extensive use of the HBV vaccine has dramatically reduced the number of incident infections in Canada and worldwide. Effective therapeutic agents have been and continue to be developed to treat chronic infection. The present review provides a comprehensive overview of diagnostic tests for HBV infection and immunity, and elaborates on HBV risk factors, vaccine prevention and therapeutic monitoring. HBV diagnosis is accomplished by testing for a series of serological markers of $\mathrm{HBV}$ and by additional testing to exclude alternative etiological agents such as hepatitis $\mathrm{A}$ and $\mathrm{C}$ viruses. Serological tests are used to distinguish acute, self-limited infections from chronic HBV infections and to monitor vaccine-induced immunity. Nucleic acid testing for HBV-DNA is increasingly being used to quantify HBV viral load and measure the effectiveness of therapeutic agents. Given the multitude of available tests and the complexity of clinical management, there is a critical need for greater coordination among clinicians, diagnostic laboratory personnel and researchers to define optimal laboratory diagnostic and monitoring assays so that the appropriate tests are used to maximize prevention and optimize treatment outcomes.

\section{Diagnostic l'hépatite B en laboratoire}

Le virus de l'hépatite B (HBV) infecte de façon chronique environ 250000 Canadiens et 350 millions de personnes dans le monde. Sans intervention, de $15 \%$ à $40 \%$ des sujets porteurs de cette infection chronique développeront éventuellement une cirrhose, une maladie hépatique terminale ou un cancer du foie, ou nécessiteront une transplantation hépatique. L'accessibilité et l'utilisation à grande échelle du vaccin anti-HBV ont considérablement réduit le nombre d'infections au Canada et dans le monde. Des agents thérapeutiques efficaces ont été et continuent d'être développés pour le traitement de l'infection chronique. Le présent article donne une vue d'ensemble des tests de dépistage de l'infection au HBV et du statut immunitaire et présente les facteurs de risque associés au virus, la prévention de l'infection par la vaccination et la surveillance des traitements. Le diagnostic de l'hépatite B s'obtient par le dépistage d'une série de marqueurs sérologiques du virus et par certains tests additionnels qui permettent d'écarter d'autres agents étiologiques, comme les virus de l'hépatite A et C. Les tests sérologiques servent à distinguer les infections aiguës spontanément résolutives des infections chroniques au HBV et à mesurer le degré d'immunité conféré par les vaccins. Le dosage de l'acide nucléique de l'ADN du HBV est de plus en plus utilisé pour quantifier la charge virale du HBV et pour mesurer l'efficacité des agents thérapeutiques. Compte tenu du grand nombre de tests disponibles et de la complexité de la gestion clinique, il faut à tout prix assurer une coordination plus grande entre les cliniciens, le personnel des laboratoires diagnostiques et les chercheurs pour définir les tests diagnostiques et les dosages de surveillance les plus efficaces en laboratoire de façon à utiliser les plus appropriés pour optimiser la prévention et le pronostic.

Key Words: Diagnosis; Hepatitis B virus; Monitoring; Prevention; Treatment

$\mathrm{O}$ the approximately 350 million individuals who are chronically infected with hepatitis B virus (HBV) worldwide, it is estimated that between 206,000 and 280,000 live in Canada $(1,2)$. Without intervention, $15 \%$ to $40 \%$ of chronic HBV-infected individuals will develop cirrhosis, end-stage liver disease, hepatocellular carcinoma, or require liver transplantation over the course of several decades $(1,3)$.

HBV is classified in the family Hepadnaviridae. It occurs as seven distinct genotypes, designated A to $\mathrm{G}$, but it is controversial as to whether the outcome of the infection is influenced by the genotype (4). HBV has a double-stranded DNA genome of approximately 3200 base pairs organized into four partially overlapping open reading frames, which encode the envelope, core (precore/core), polymerase and X proteins. The envelope proteins are surface glycoproteins collectively designated as hepatitis B surface antigen (HBsAg). In virusinfected liver cells, HBsAg is produced in excess and secreted into the blood, where it serves as a marker for active infection and infectivity. Currently, recombinant HBsAg is used for $\mathrm{HBV}$ vaccination, and the development of antibody to $\mathrm{HBs} \mathrm{Ag}$ is typically associated with protective immunity. The core open reading frame encodes a polypeptide that is expressed as either the hepatitis $\mathrm{B}$ e antigen ( $\mathrm{HBeAg}$ ) or the viral capsid protein $(\mathrm{HBcAg})$. The presence of detectable $\mathrm{HBeAg}$ in serum or plasma is associated with high levels of HBV replication, greater infectivity and an increased risk of hepatic fibrosis. Mutations in the core promoter and precore regions result in decreased levels or an absence of detectable HBeAg in the serum, but this may not alter the sequelae of chronic infection. The polymerase protein functions as a reverse transcriptase, 


\section{TABLE 1}

Risk factors for viral hepatitis, including hepatitis $B$ virus

- Substance abuse (injection drug use, snorting cocaine)

- High-risk sexual activities (eg, rectal intercourse)

- Multiple sexual partners

- A sexual partner with viral hepatitis

- Persons coming from or travelling to high-risk hepatitis endemic areas

or exposure to a local outbreak

- Household contact or sharing of personal items with an infected person

- Attendance at daycares

- History of a transfusion-dependent illness

- Needle-stick injury or other occupational exposure

(eg, nonimmune health care workers)

- Newborns of infected mothers

- Tattoos and/or body piercing using nonsterile techniques

a DNA polymerase and a terminal protein. The $\mathrm{X}$ protein functions as a transactivator, which may have an important role in hepatocellular carcinogenesis.

Given the availability of safe and effective vaccines, a major global public health goal is the prevention of the spread of this virus (5). Unfortunately, the estimated 350 million chronically infected people remain an ongoing source of infection, and the spread of this virus will only be stopped after several generations of targeted vaccination (6). Vaccination programs have focused on eliminating perinatal transmission to neonates, where the risk of developing chronic infection is $70 \%$ to $95 \%$, and to young infants (toddlers), where the risk of developing chronic infection is estimated at 30\%. Sexual transmission and injection drug use are major risk factors for acquiring infection in young adults and a major cause of incident infections in North America (5) (Table 1). Although fewer than $5 \%$ of acutely infected young adults develop chronic infection, virtually all infections can be completely prevented by vaccination $(1,5)$.

A secondary public health goal is to prevent the morbidity and mortality associated with chronic HBV infection. Foremost is to counsel infected individuals to abstain from alcohol. In chronic carriers, alcohol consumption of more than $40 \mathrm{~g} /$ day has been associated with elevated aminotransferases and an increased risk of progressive liver disease. Treatment of chronic HBV infection is evolving rapidly and has recently been the subject of several reviews $(3,7)$. Drugs currently licensed include interferon-alpha, lamivudine and famciclovir. Adefovir dipivoxil has been licensed in the United States. Many promising new antiviral agents, such as entecavir, emtricitabine, clevudine, tenofovir, telbivudine and pegylated interferons, are in clinical trials or under development. These drugs, perhaps used in combination, hold the promise of resolving chronic infection and its sequelae.

\section{General considerations}

The present guideline addresses tests for the diagnosis and management of HBV. Because hepatitis A virus (HAV) causes acute infection and hepatitis $\mathrm{C}$ virus (HCV) causes both acute and chronic infections, and because both are common in North America, diagnostic tests for HAV and HCV are included as part of the comprehensive workup. Additional information on the diagnosis and management of HCV infection can be found elsewhere $(8,9)$. It must also be recognized that coinfections and superinfections with other hepatitis viruses (eg, HCV) may occur. Although hepatitis D and hepatitis E viral infections are rare in Canada, these agents should be considered along with other viruses, namely, cytomegalovirus, Epstein-Barr virus, enteroviruses, hepatotoxic drugs, and even herbal medicines when appropriate. Finally, a person's history, age, risk factors (Table 1), vaccination status and previous tests results should be used to guide appropriate testing.

\section{SPECIMEN CHOICE, COLLECTION AND TRANSPORT}

The specimen of choice for the diagnosis of HBV infection is blood. Serological tests for viral antigens and antibodies are typically used for diagnostic screening and can be performed on either serum or plasma. Both HBV antigens and antibody are stable at room temperature for days, at $4^{\circ} \mathrm{C}$ for months, and frozen at $-20^{\circ} \mathrm{C}$ to $-70^{\circ} \mathrm{C}$ for many years. Because modern testing involves automated enzyme immunoassays that depend on colourimetic or chemiluminescence signal measurement, care should be taken to avoid hemolysis of the sample because it may interfere with the ability of the assay to accurately detect these markers.

A number of nucleic acid-based tests, which have been the subject of recent reviews $(10,11)$, are available to directly detect HBV-DNA in serum or plasma. Care must be taken to avoid the degradation of the viral nucleic acid in the specimen, which can result in falsely low or no measurable viral load. Serum should therefore be removed from clotted blood within $4 \mathrm{~h}$ of collection and stored at $-20^{\circ} \mathrm{C}$ to $-70^{\circ} \mathrm{C}(12)$, and can be subjected to up to eight short-term freeze-thaw cycles without significant loss of detectable HBV-DNA (13). Alternatively, the presence of EDTA in plasma is known to stabilize viral nucleic acids. EDTA blood can be stored for up to five days at $4^{\circ} \mathrm{C}$ without affecting the viral load (14). Polymerase chain reaction-based tests can use either serum or plasma, while hybridization-based assays (eg, Digene Corporation, USA) recommend the use of serum.

\section{EVALUATION OF INDIVIDUALS SUSPECTED OF HAVING AN HBV INFECTION}

Given the perinatal and childhood vaccination programs already in place in North America, most HBV-infected individuals will likely present with chronic infection. Such individuals are likely to have risk factors that include immigration from high endemicity regions, injection drug use or sexual contact with an infected person (Table 1) (5). Therefore, the present guideline will provide diagnostic recommendations first for individuals suspected of having chronic HBV infection and, subsequently, for those with acute infection. The diagnosis of HBV infection in any individual has important management implications, including appropriate counselling, monitoring and/or treating and vaccinating family or at-risk contacts.

\section{RECOMMENDED TESTS TO INVESTIGATE CHRONIC HBV INFECTION, AND THE INTERPRETATION OF RESULTS}

Chronic HBV infection is defined by the continued presence of HBsAg in the blood for longer than six months. Figure 1 and Table 2 outline the tests used to diagnose most cases of chronic HBV. Test selection should be based on the person's risk factors, vaccination history and findings from previous tests (see section on determining HBV immunity). 


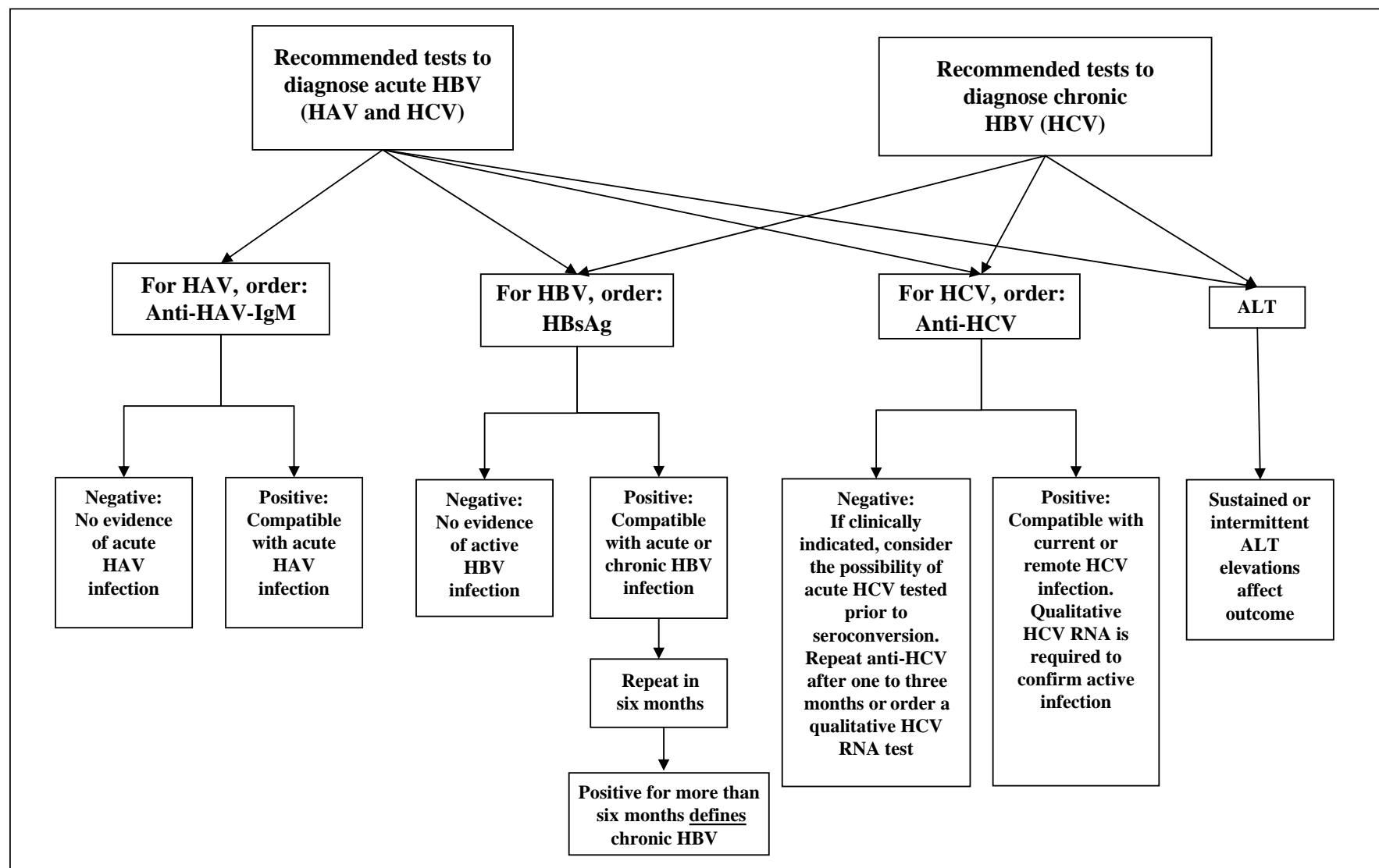

Figure 1) Diagnostic tests for acute or chronic hepatitis B virus (HBV) infection (diagnostic tests for acute hepatitis A virus [HAV] and acute and chronic hepatitis $\mathrm{C}$ virus [HCV] are included for completeness). ALT Alanine aminotransferase; Anti-HAV-IgM Immunoglobulin M class antibody to HAV; Anti-HCV Antibody to HCV antigens; HBsAg Hepatitis B surface antigen

\section{TABLE 2}

Primary and secondary tests to diagnose/monitor hepatitis B virus (HBV) infection

\begin{tabular}{|c|c|c|c|c|c|c|}
\hline & Marker & Incubation period & Acute infection & Past/resolved infection & Chronic infection & Vaccination \\
\hline \multicolumn{7}{|l|}{ Primary diagnostic tests } \\
\hline & $\mathrm{HBsAg}$ & \pm & + & - & + & $-^{*}$ \\
\hline & Anti-HBs & - & - & + & - & + \\
\hline & Anti-HBc-IgM & - & + & - & $\pm^{\dagger}$ & - \\
\hline \multicolumn{7}{|l|}{ Prognostic or monitoring tests } \\
\hline & $\mathrm{HBeAg}$ & \pm & + & - & \pm & - \\
\hline & HBV-DNA § & $\pm \S$ & + & $\pm \S$ & $+\S$ & - \\
\hline
\end{tabular}

${ }^{*}$ Recent HBV vaccination within one to two weeks can lead to a false-positive test. The vaccine antigen can be detected at low levels; ${ }^{\dagger}$ May be positive in chronically infected individuals; ${ }^{\ddagger}$ Patients with chronic HBV infection usually have detectable Hepatitis B e antigen (HBeAg) or antibody to hepatitis B e protein (anti-HBe). Rarely, both $\mathrm{HBeAg}$ and anti-HBe can be detected simultaneously; §Methods differ in sensitivity and standardization. Anti-HBc Antibody to hepatitis B core protein; Anti-HBs Antibody to hepatitis B surface protein; HBsAg Hepatitis B surface antigen; IgM Immunoglobulin M; + Implies positive; - Implies negative; \pm May be positive or negative

HBsAg

- If negative, chronic HBV infection is typically ruled out (15).

- If positive, the patient is considered HBV-infected. Chronic infection is diagnosed when the HBsAg remains detectable for greater than six months.

Total antibody to hepatitis B core protein

- If negative, past infection with HBV is typically ruled out.

- If positive, the patient has been infected with HBV (15). Infection may be resolved (HBsAg-negative) or ongoing
(HBsAg-positive). If the infection is resolved, the person is considered naturally immune to $\mathrm{HBV}$ infection.

Antibody to hepatitis B surface protein

- If negative, the patient has no apparent immunity to HBV (see section on measuring HBV immunity).

- If positive, the patient is considered immune to HBV (either because of resolved infection or as the result of prior vaccination). Very rarely (less than $1 \%$ ) can chronic carriers be positive for HBsAg and antibody to hepatitis B surface protein (anti-HBs) at the same time (15). In such cases, the patient is considered infectious. 


\section{Serum transaminases}

Once an individual has been diagnosed with chronic HBV infection, follow-up testing must be performed for alanine aminotransferase (ALT), a marker of liver cell inflammation (15). Repeat periodic testing is indicated because the ALT levels can fluctuate (eg, from less than the upper limit of normal to intermittently or consistently elevated). Sustained and intermittent elevations in ALT beyond the upper limit of normal are indicative of hepatic inflammation and correlate with an increased risk of progressive liver disease $(3,7)$. It must be noted that the normal ALT ranges are both age and sex dependent and that, occasionally, individuals with severe liver disease may not manifest elevated ALT $(15,16)$.

\section{Antibody to $\mathrm{HCV}$ antigens}

- If negative, chronic HCV infection is ruled out in immunocompetent individuals. Because the antibody to $\mathrm{HCV}$ antigens (anti-HCV) response in immunocompromised persons can be blunted, a qualitative test for HCV-RNA may be required to rule out occult infection in such individuals. A new HCV core antigen test, which is currently under evaluation, can also be used to confirm active infection $(17,18)$. However, the currently available HCV core antigen test is less sensitive, detecting less than $90 \%$ to $95 \%$ of HCV-RNA-positive specimens (17-19). Therefore, the current HCV core antigen should not be used for definitive exclusion of active infection.

- If found to be anti-HCV positive, the patient has been infected with HCV. Because most HCV infections are chronic (mean $75 \%$, range $50 \%$ to $85 \%$ ), the presence of anti-HCV is correlated with active infection; however, a qualitative test for HCV-RNA is currently required to confirm active HCV infection $(20,21)$.

\section{RECOMMENDED TESTS TO INVESTIGATE ACUTE HBV INFECTION, AND THE INTERPRETATION OF RESULTS}

Acute HBV infection generally presents after an incubation period of six weeks to several months with an onset of nonspecific symptoms that may include fever, malaise, anorexia and nausea, followed by the onset of jaundice, dark urine and pale stools. Approximately $25 \%$ to $40 \%$ of infected adults will be symptomatic, and most will demonstrate elevations in ALT; however, infants, toddlers and immunosuppressed individuals may not manifest signs (eg, jaundice) or symptoms of infection. The management of acute infections is largely supportive unless fulminant hepatitis develops, in which case the patient should be referred to a liver specialist. Because the clinical features of acute hepatitis are very similar for HAV, HBV and HCV, testing for all three agents should be performed when working up an acute case. While the sexual transmission of $\mathrm{HCV}$ is rare, varying between zero to six cases per 1000 person-years (22), HAV that is typically spread by the fecal-oral route poses a clear risk to sexual partners. Figure 1 and Table 2 outline the appropriate serological tests to investigate acute hepatitis.

\section{HBsAg}

- If negative, acute HBV infection is ruled out (15).
- If positive, the patient is infected with HBV. A repeat test after six months will determine if the infection has resolved or is chronic.

\section{Anti-HBs}

- If negative, the patient has no apparent immunity to HBV (see section on measuring HBV immunity).

- If positive, the patient is considered immune to HBV (either because of resolved infection or vaccination).

\section{Anti-HBc-immunoglobulin M}

In rare cases, anti-HBc-immunoglobulin (Ig) $\mathrm{M}$ may be the only HBV marker detected during the early convalescence or 'window period' when the HBsAg and anti-HBs tests are negative. Because current tests for $\mathrm{HBs} A g$ are very sensitive, an anti-HBc-IgM that is typically positive with acute HBV infection is not generally required to diagnose active infection. Because some chronic HBV carriers remain anti-HBc-IgM positive for years, epidemiological information is necessary to confirm that the infection is indeed acute. A negative anti$\mathrm{HBc}-\mathrm{IgM}$ in the presence of a positive HBsAg suggests that the infection is likely chronic. For these reasons, routine testing for anti-HBc-IgM is not generally recommended to screen for acutely infected patients.

\section{IgM class antibody to HAV}

- If the IgM class antibody to HAV (anti-HAV-IgM) is negative, HAV infection is ruled out in immunocompetent patients (15).

- If positive, acute HAV infection is likely. As the anti-HAV-IgM may remain detectable for up to two years after infection in a small subset of patients, the history and clinical presentation must be considered in making an accurate diagnosis (15).

\section{Anti-HCV}

- If the anti-HCV is negative, acute infection is ruled out in most immunocompetent individuals. Detection of seroconversion typically requires at least five to six weeks after acute infection. Acute infection can be confirmed or ruled out by either repeating the anti-HCV test within one to three months or by performing a qualitative HCV-RNA test. The qualitative HCV-RNA test is typically positive within two weeks after infection. If the patient is immunocompromised, a qualitative test for HCV-RNA may be required to confirm or rule out active infection $(9,23)$.

- If the anti-HCV is positive, the individual has been infected with HCV. Because most HCV infections lead to chronic infection (mean $75 \%$, range $50 \%$ to $85 \%$ ), the presence of anti-HCV is generally correlated with active infection. However, a qualitative test for HCV-RNA is currently required to confirm active HCV infection.

\section{ALT}

- ALT is typically elevated in individuals with acute viral hepatitis (15). 


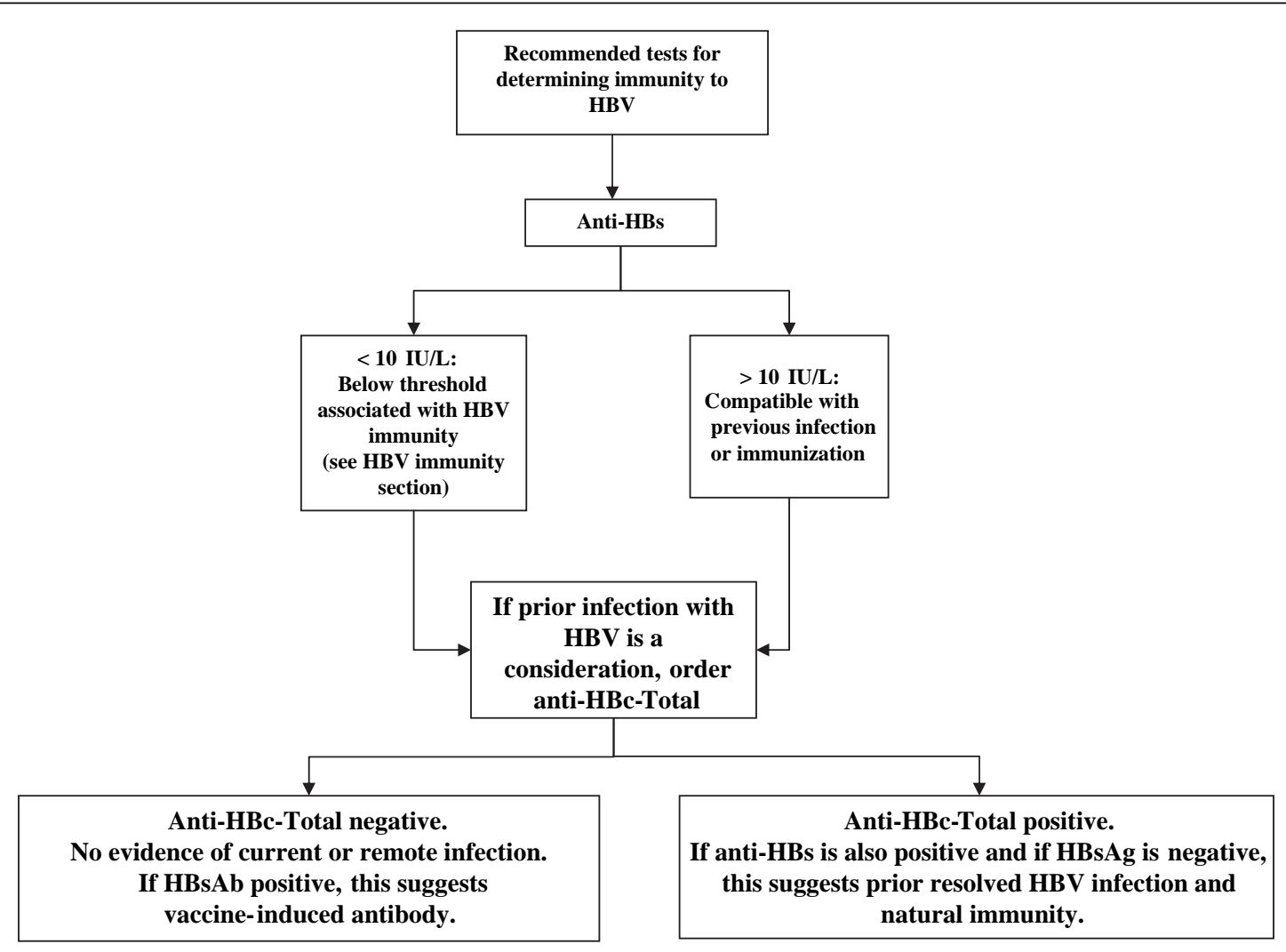

Figure 2) Investigation of hepatitis B virus (HBV) immunity. Anti-HBc-Total Total antibody to hepatitis B core protein; Anti-HBs/HBsAb Antibody to hepatitis B surface antigen

\section{ASSESSMENT OF HBV IMMUNE STATUS}

Immunity to HBV is acquired from a resolved infection or from vaccination (Figure 2 ). The $\mathrm{HBV}$ vaccine has been shown to induce protective immunity in $90 \%$ to $95 \%$ of vaccinees. Most vaccinees will have protective levels of anti-HBs for five to 10 years after vaccination, although the exact duration of immunity remains undefined. When anti-HBs levels have waned below the protective threshold of $10 \mathrm{mIU} / \mathrm{mL}$, a booster dose of HBV vaccine has been shown to induce a strong anamnestic immune response in such individuals. It is therefore probable that protection from chronic HBV infection may last for decades and may well be lifelong (5).

The HBV immune status can be determined using the tests outlined below, but testing for vaccine immunity in the general population is not indicated unless the individual is at high risk of infection (Figure 2, Table 3). Nonimmune individuals should be offered HBV vaccination where clinically appropriate.

\section{RECOMMENDED TESTS TO DETERMINE IMMUNITY TO HBV, AND THE INTERPRETATION OF RESULTS}

\section{Anti-HBs}

- If the anti-HBs level is less than $10 \mathrm{mIU} / \mathrm{mL}$, this implies that the person is nonimmune to HBV. In individuals who have received a complete course of HBV vaccine, the level of antiHBs may drop to less than $10 \mathrm{mIU} / \mathrm{mL}$ after five to 10 years, but these individuals are generally considered to be immune based on their vaccination history (5).
TABLE 3

Persons at high risk of hepatitis B virus (HBV) for whom testing for immunity is indicated

- Neonates born to HBV carrier mothers

- Sexual partners of HBV-infected individuals

- Household contacts of HBV-infected individuals

- Immunocompromised individuals (eg, persons undergoing dialysis)

- Health care workers and others at occupational risk of exposure

(eg, needle-stick injury)

- Visitors to regions with high HBV endemicity

- People with chronic hepatitis $\mathrm{C}$ virus or other chronic liver diseases (eg, alcoholic cirrhosis, hemochromatosis, biliary cirrhosis)

- If the anti-HBs result is greater than $10 \mathrm{mIU} / \mathrm{mL}$, the person is considered to be immune. Immunity may be due to immunization or resolved natural infection. These two states can be distinguished by testing for total antibody to hepatitis B core protein (anti-HBc-Total), which is present in subjects that have had HBV infection but absent in vaccinees (see below).

Anti-HBc-Total:

- If the anti-HBc-Total test is negative, the patient has no evidence of current or remote HBV infection.

- If the anti-HBc-Total test is positive, this is compatible with current or resolved HBV infection. A negative $\mathrm{HBsAg}$ confirms a resolved infection. HBV vaccination does not induce anti-HBc-Total. 


\section{TABLE 4}

Commercially available hepatitis B virus (HBV) DNA detection assays

\begin{tabular}{|c|c|c|}
\hline Assay type and manufacturer & Method & Detection range \\
\hline $\begin{array}{l}\text { HBV Digene Hybrid-Capture I, } \\
\text { Digene Corporation, USA }\end{array}$ & Hybrid Capture, tube-based signal amplification & $1,400,000$ copies $/ \mathrm{mL}$ to $560,000,000$ copies $/ \mathrm{mL}$ \\
\hline $\begin{array}{l}\text { HBV Digene Hybrid-Capture II, } \\
\text { Digene Corporation, USA }\end{array}$ & Hybrid capture, plate-based signal amplification & $\begin{array}{l}142,000 \text { copies } / \mathrm{mL} \text { to } 1,700,000,000 \text { copies } / \mathrm{mL} \text { for } \\
\text { standard format; } 4,700 \text { to } 57,000,000 \text { for the } \\
\text { ultrasensitive format (after centrifugation) }\end{array}$ \\
\hline $\begin{array}{l}\text { Cobas AMPLICOR HBV Monitor } \\
\text { Roche Molecular Systems, USA }\end{array}$ & Semi-automated quantitative polymerase chain reaction & 200 copies $/ \mathrm{mL}$ to 200,000 copies $/ \mathrm{mL}$ \\
\hline $\begin{array}{l}\text { Versant HBV-DNA 1.0 Assay (bDNA) } \\
\text { Bayer Diagnostics, USA }\end{array}$ & Plate-based branched DNA signal amplification & $\begin{array}{l}700,000 \text { genome equivalents } / \mathrm{mL} \text { to } \\
5,000,000,000 \text { genome equivalents } / \mathrm{mL}\end{array}$ \\
\hline $\begin{array}{l}\text { Versant HBV-DNA 3.0 Assay (bDNA) } \\
\text { Bayer Diagnostics, USA }\end{array}$ & Plate-based branched DNA signal amplification & 3,300 copies $/ \mathrm{mL}$ to $100,000,000$ copies $/ \mathrm{mL}$ \\
\hline
\end{tabular}

\section{ADDITIONAL TESTS AND RARE OR UNUSUAL FINDINGS IN TESTING FOR HEPATITIS VIRUS MARKERS}

Although findings from the above test results provide essential information to establish a definitive diagnosis of most HBV cases, additional tests may be required to establish the diagnosis for atypical presentations.

\section{Anti-HBc-IgM}

While patients with acute HBV infection are typically seropositive for anti-HBc-IgM, this antibody may also be detected in a subset of chronic carriers. Occasionally, this antibody is the only marker of infection present in the early convalescence 'window period' when the HBsAg and anti-HBs tests are both undetectable. Because current tests for HBsAg are very sensitive, the absence of anti-HBc-IgM is generally useful to exclude an acute infection, and its presence can assist in defining an acute infection.

\section{Anti-HBc-Total}

Very rarely, a positive anti-HBc-Total will be the only detectable marker of a past HBV infection. Under such circumstances, it is not possible to confirm such a finding by testing for other markers. It is prudent to consider such individuals as nonimmune to HBV and to offer them a course of $\mathrm{HBV}$ vaccination.

\section{$\mathrm{HBeAg}$}

The presence of this marker correlates with high infectivity and, in chronic carriers, with an enhanced risk of progression to cirrhosis. This test can be selectively used to help follow the evolution of chronic HBV.

\section{Antibody to hepatitis B e protein}

The presence of this marker in chronic carriers generally denotes a less infectious state and a partial resolution of HBV infection. Occasionally, carriers can demonstrate both $\mathrm{HBeAg}$ and antibody to hepatitis B e protein (anti-HBe).

\section{HBV-DNA}

The presence of HBV-DNA in serum or plasma denotes active HBV infection and, depending on the viral load, correlates with the infectivity of the patient. Tests vary in terms of sensitivity and standardization (Table 4). These tests can be used to assess prognosis and guide HBV treatment.

\section{MANAGEMENT OF CHRONIC HBV INFECTION} Chronic HBV carriers at greatest risk of hepatic sequelae Sustained elevations in ALT, although an imperfect marker for hepatic damage, can help identify chronic HBV carriers at greatest risk of sequelae and those most likely to benefit from current treatments $(7,16,24,25)$. Chronically infected patients with sustained ALT elevations greater than the upper limit of normal may be candidates for treatment and should undergo additional prognostic hepatitis marker testing as outlined below. Chronic carriers whose ALT is within the normal range should be tested for this marker periodically because ALT levels can fluctuate with this illness. Determination of ALT levels and HBV serological and nucleic acid markers, although valuable in following infection, is not adequate to assess the severity of infection and the resulting liver damage. Before appropriate treatment can be initiated, consultation with a specialist and assessment of the disease through histological examination of a liver biopsy is strongly recommended.

Testing for appropriate biochemical and virological markers at defined intervals can be used to follow the progression or resolution of chronic HBV infection. The presence of $\mathrm{HBeAg}$ is correlated with high levels of viral replication as measured by HBV-DNA $(10,26)$ and a higher risk of cirrhosis and hepatocellular carcinoma $(1,27)$. The sustained return of ALT levels to the normal range typically implies a favourable prognosis and reflects a decrease in the level of inflammation. The loss of HBeAg, development of anti-HBe and decrease of HBV-DNA level below $10^{5}$ copies $/ \mathrm{mL}$ is consistent with a partial resolution of the infection. Such patients are also considered to be less infectious and at decreased risk for the development of hepatocellular carcinoma. Complete resolution, which is rare with antiviral therapy, is achieved with the loss of HBsAg and the appearance of anti-HBs.

Antiviral therapy has been used only to a limited extent for the treatment of chronic HBV infection; the outcomes of such treatment have not been consistently measured. For example, $15 \%$ to $50 \%$ of treated HBV patients will respond to a course of interferon-alpha or long-term lamivudine treatment (3). Individuals with higher baseline ALT levels have been shown to be more likely to respond (3). Seroconversion from an HBeAg-positive status to an anti-HBe-positive status has traditionally been used to indicate treatment response and results in a reduced morbidity and mortality (Table 2 ). Individuals infected with HBV that is genotypically associated with precore mutations may not have detectable HBeAg. For these individuals, the 
response to treatment can only be monitored through HBVDNA testing (7). With current treatments, the complete loss of $\mathrm{HBs} \mathrm{Ag}$ is rarely observed, generally occurring in fewer than $10 \%$ of responders, and complete viral elimination may not be possible in any case because HBV-DNA may remain in liver cells (1).

\section{Management of pregnant HBV carriers}

Pregnant HBV carrier mothers present a unique opportunity to prevent transmission of HBV to their neonates. All infants born to $\mathrm{HBs} A g$-positive mothers should receive hepatitis B immune globulin and a full course of HBV vaccination (5). Vaccine failure in the neonate is rare but does occur (fewer than $10 \%$ of prophylaxed neonates), and may be accounted for by transplacental transmission before birth. Follow-up testing of the neonate should be performed to confirm vaccination effectiveness. Testing should be performed for HBsAg to detect vaccine failures, anti-HBs to confirm a successful vaccine response and anti$\mathrm{HBc}$-Total to determine if the anti-HBs response was due to vaccination or resolution of natural infection. While testing for these markers is recommended one to two months after completion of the vaccine series, testing at approximately 18 months would ensure that the anti-HBc-Total test does not represent maternal antibody. This may be important because vaccination failures have occasionally been associated with $\mathrm{HBV}$ vaccine escape mutants that may only demonstrate a positive anti-HBcTotal as the sole marker of infection. These mutations occur in the open reading frame of the HBsAg, may not be recognized by antibodies induced by current HBV vaccine, and may not be detected by currently available $\mathrm{HBs} A g$ enzyme immunoassays $(28,29)$. Clearly, surveillance systems need to be in place to ensure that $\mathrm{HBV}$ vaccines remain effective and vaccine escape mutants do not replace current HBV strains.

\section{Measuring and interpreting HBV-DNA levels}

Four commercially available HBV-DNA tests and their detection ranges are outlined in Table 4 . Because of limited nucleic acid assay standardization (30) and the fact that manufacturers of HBV-DNA assays have not as yet adopted an international HBV-DNA standard (31), interassay comparisons have resulted in 10-fold or greater variations in the reported HBV-DNA level when testing the same specimen $(10,11)$. Intra-assay variation also occurs and ranges from $10 \%$ to $40 \%$ depending on the methodology used. The reported detection ranges for the various assays are very different (Table 4). Hybridization-based assays are 30-fold to 10,000-fold less sensitive than commercial polymerase chain reaction-based assays. Because chronically infected individuals can have between zero to $10^{10}$ copies/mL of HBV-DNA in serum or plasma and current HBV-DNA assays have detection ranges of $3 \log _{10}$ to $5 \log _{10}$, the quantitative accuracy will only be valid if the person's viral load falls within the detection range of the assay. Thus, the interpretation of an HBV-DNA test result must be made in the context of the specific test used. For example, specimens from individuals with high levels of viremia, typically those who are HBeAg-positive, may have to be diluted before retesting to accurately quantify the HBV-DNA. Alternatively, the inability to detect HBV-DNA using a relatively insensitive hybridization assay does not confirm that the virus is absent from the blood. The expected adoption of an HBV-DNA international standard will greatly improve interassay standardization and should facilitate the correlation between clinical status and laboratory findings.

\section{Detection of antiviral resistance}

Lamivudine monotherapy has been reported to be associated with the rapid emergence of antiviral resistance in 15\% to $60 \%$ of treated individuals $(7,32)$. Resistant HBV genomes have mutations in codon 552 (204) within the YMDD motif (tyrosine-methionine-aspartic acid-aspartic acid) of the reverse transcriptase/polymerase where a valine or isoleucine replaces the methionine. Resistance is typically clinically manifested by significant elevations in ALT after an initial decline in response to treatment. Prolonged treatment after development of the YMDD mutant is controversial, although improvement in liver pathology with decreased fibrosis may occur with continuation of treatment. Concerns about disease flares after stopping lamivudine have been raised (7). The development of genotypic resistance can be documented by molecular sequencing or by the INNO-LiPA HBV DR assay (Innogenetics Inc, USA), which involves hybridization of amplified HBV-DNA fragments onto specific nucleotide probes that have been immobilized on nitrocellulose strips (33).

Newer agents such as adefovir, dipivoxil and entecavir have been reported to be active against lamivudine-resistant HBV $(34,35)$. Combination therapies with interferon and lamivudine appear to enhance the overall response rate, but the efficacy of newer pegylated interferons in combination and combinations of nucleoside analogues remains to be assessed (36). Given the relatively poor performance of current monotherapies, it is likely that combinations of nucleoside analogues with or without interferon will be required to enhance the long-term efficacy of antiviral treatment. There is also a pressing need for more standardized serological and/or nucleic acid assays and tests for other markers that predict the patients most likely to have durable treatment responses and/or define the optimal treatment duration.

\section{Screening for hepatocellular carcinoma}

The most important risk factor for hepatocellular carcinoma is prolonged chronic HBV infection for decades, particularly in patients with active disease based on elevated ALT levels (27). The development of cirrhosis in chronic carriers increases the risk of developing hepatocellular carcinoma, although in the case of HBV, the latter may occur in the absence of cirrhosis. Although the cost benefit remains to be established, screening for hepatocellular carcinoma is suggested in patients 30 years of age or older with one or more of the following risk factors (37): infection at birth (perinatal/vertical transmission); being male; a duration of infection for several decades; a family history of hepatocellular carcinoma; the presence of HCV co-infection; and finally, specific at-high-risk populations (eg, Asian and refugee populations from $\mathrm{HBV}$ endemic regions). Suggested screening consists of an abdominal ultrasound and serum alpha-fetoprotein at approximately six-month intervals (37).

\section{Continuous quality improvement}

An effective continuous quality improvement program integrates quality control, quality assurance and proficiency testing. Laboratories typically participate in provincial, national and/or international proficiency programs evaluating test performance and interpretive accuracy. These programs are critical in evaluating interlaboratory reliability and reproducibility. Quality control monitoring includes ensuring the specimen is collected and handled appropriately, having procedures in place to detect and act on process and procedural errors, ensuring test reagents are functioning as per the manufacturer's specifications 
and recognizing abnormal results and implementing control measures to ensure that the analytical testing process is accurate. Monitoring of lot-to-lot test kit reproducibility can be facilitated by the use of external controls.

Quality assurance of HBV testing is challenging. There is a broad array of analytical tests needed to assess the status of the infection. Clinicians may not be aware of the appropriate tests to request or may not be knowledgeable in their interpretation. For example, multiple tests over a period of time may be required to confirm whether a new infection resolves or becomes chronic. Individuals may be seen by multiple clinicians who may not have available the findings from previous testing or be aware of the vaccination status, leading to needless duplication of testing.

When multiple laboratories are involved in the testing of different hepatitis virus markers, no comprehensive summary of test

\section{REFERENCES}

1. Lee WM. Hepatitis B virus infection. N Engl J Med 1997;337:1733-45.

2. Canadian Association for the Study of the Liver. Canadian consensus conference on the management of viral hepatitis. Can J Gastroenterol 2000;14(Suppl B):5B-20.

3. Lok AS, McMahon BJ; Practice Guidelines Committee, American Association for the Study of Liver Diseases. Chronic hepatitis B. Hepatol 2001;34:1225-41.

4. Stuyver L, De Gendt S, Van Geyt C, et al. A new genotype of hepatitis $\mathrm{B}$ virus: Complete genome and phylogenetic relatedness. J Gen Virol 2000;81:67-74.

5. Mahoney FJ. Update on diagnosis, management and prevention of hepatitis B virus infection. Clin Microbiol Rev 1999;12:351-66.

6. Margolis HS. Prevention of acute and chronic liver disease through immunization: Hepatitis B and beyond. J Infect Dis 1993;168:9-14.

7. Wai CT, Lok AS. Treatment of hepatitis B. J Gastroenterol 2002;37:771-8.

8. Lauer GM, Walker BD. Hepatitis C virus infection. N Engl J Med 2001;345:41-52.

9. Krajden M. Hepatitis C virus diagnosis and testing. Can J Public Health 2000;91(Suppl 1):S34-9.

10. Pawlotsky JM. Molecular diagnosis of viral hepatitis. Gastroenterology 2002;122:1554-68.

11. Krajden M, Minor J, Cork L, Comanor L. Multi-measurement method comparison of three commercial hepatitis B virus DNA quantification assays. J Viral Hepat 1998;5:415-22.

12. Krajden M, Comanor L, Rifkin O, Grigoriew A, Minor JM, Kapke GF. Assessment of hepatitis B virus DNA stability in serum by the Chiron Quantiplex branched-DNA assay. J Clin Microbiol 1998;36:382-6.

13. Krajden M, Minor JM, Rifkin O, Comanor L. Effect of multiple freezethaw cycles on hepatitis $B$ virus DNA and hepatitis $C$ virus RNA quantification as measured with branched-DNA technology. J Clin Microbiol 1999;37:1683-6.

14. Grant PR, Kitchen A, Barbara JA, et al. Effects of handling and storage of blood on the stability of hepatitis $\mathrm{C}$ virus RNA: Implications for NAT testing in transfusion practice. Vox Sang 2000;78:137-42.

15. Dufour DR, Lott JA, Nolte FS, Gretch DR, Koff RS, Seeff LB. Diagnosis and monitoring of hepatic injury. I. Performance characteristics of laboratory tests. Clin Chem 2000;46:2027-49.

16. Prati D, Taioli E, Zanella A, et al. Updated definitions of healthy ranges for serum alanine aminotransferase levels. Ann Intern Med 2002;137:1-10.

17. Tanaka E, Ohue C, Aoyagi K, et al. Evaluation of a new enzyme immunoassay for hepatitis $\mathrm{C}$ virus $(\mathrm{HCV})$ core antigen with clinical sensitivity approximating that of genomic amplification of HCV RNA. Hepatology 2000;32:388-93.

18. Icardi G, Ansaldi F, Bruzzone BM, et al. Novel approach to reduce the hepatitis $\mathrm{C}$ virus (HCV) window period: Clinical evaluation of a new enzyme-linked immunosorbent assay for HCV core antigen. J Clin Microbiol 2001;39:3110-4.

19. Krajden M, Shivji R, Gunadasa K, et al. Evaluation of the core antigen assay as a second-line supplemental test for diagnosis of active hepatitis C virus infection. J Clin Microbiol 2004;42:4054-9. results may be available; hence, the laboratories may be unable to employ best laboratory practices to support appropriate utilization. Clinical information is often not conveyed to the laboratory, making it difficult to select the appropriate tests (eg, acute versus chronic infection). Although published guidelines can help streamline the ordering of tests, ensuring that the guidelines properly address the broad clinical presentations remains a challenge. Given the complexity of hepatitis testing, it is likely that an electronic and universally accessible longitudinal patient record of test results would be the most effective way to optimize test utilization and provide the appropriate results to the clinician. As antiviral treatments are rapidly evolving, there is clearly a need for greater cooperation between clinicians, laboratories and researchers to define laboratory outcomes so that treatment efficacy can be enhanced and measured more effectively.

20. Alter MJ, Kruszon-Moran D, Nainan OV, et al. The prevalence of hepatitis C virus infection in the United States, 1988 through 1994. N Engl J Med 1999;341:556-62.

21. Jaeckel E, Cornberg M, Wedemeyer H, et al. Treatment of acute hepatitis C with interferon alfa-2b. N Engl J Med 2001;345:1452-7.

22. Terrault NA. Sexual activity as a risk factor for hepatitis C. Hepatology 2002;36(5 Suppl 1):S99-105.

23. Richter SS. Laboratory assays for diagnosis and management of hepatitis $\mathrm{C}$ virus infection. J Clin Microbiol 2002;40:4407-12.

24. Pratt DS, Kaplan MM. Evaluation of abnormal liver-enzyme results in asymptomatic patients. N Engl J Med 2000;342:1266-71.

25. Sato A, Kato Y, Nakata K, et al. Relationship between sustained elevation of serum alanine aminotransferase and progression from cirrhosis to hepatocellular carcinoma: Comparison in patients with hepatitis B virus- and hepatitis $C$ virus-associated cirrhosis. J Gastroenterol Hepatol 1996;11:944-8.

26. Chu CJ, Hussain M, Lok AS. Quantitative serum HBV DNA levels during different stages of chronic hepatitis B infection. Hepatology 2002;36:1408-15.

27. Yang HI, Lu SN, Liaw YF, et al. Hepatitis B e antigen and the risk of hepatocellular carcinoma. N Engl J Med 2002;347:168-74.

28. Zuckerman AJ. Effect of hepatitis B virus mutants on efficacy of vaccination. Lancet 2000;355:1382-4.

29. Zuckerman AJ, Zuckerman JN. Molecular epidemiology of hepatitis B virus mutants. J Med Virol 1999;58:193-5.

30. Quint WG, de Bruijn I, Kruining H, Heijtink RA. HBV-DNA detection by gene amplification in acute hepatitis B. Hepatology 1990;12:653-6.

31. Heermann KH, Gerlich WH, Chudy M, Schaefer S, Thomssen R. Quantitative detection of hepatitis B virus DNA in two international reference plasma preparations. Eurohep Pathobiology Group. J Clin Microbiol 1999;37:68-73.

32. Leung NW, Lai CL, Chang TT, et al. Extended lamivudine treatment in patients with chronic hepatitis B enhances hepatitis B e antigen seroconversion rates: Results after 3 years of therapy. Hepatology 2001;33:1527-32.

33. Lok AS, Zoulim F, Locarnini S, et al. Monitoring drug resistance in chronic hepatitis B virus (HBV)-infected patients during lamivudine therapy: Evaluation of performance of INNO-LiPA HBV DR assay. J Clin Microbiol 2002;40:3729-34.

34. Perrillo R, Schiff E, Yoshida E, et al. Adefovir dipivoxil for the treatment of lamivudine-resistant hepatitis B mutants. Hepatology 2000;32:129-34.

35. Levine S, Hernandez D, Yamanaka G, et al. Efficacies of entecavir against lamivudine-resistant hepatitis $B$ virus replication and recombinant polymerases in vitro. Antimicrob Agents Chemother 2002;46:2525-32.

36. Schalm S, De Man R, Janssen H. Combination and newer therapies for chronic hepatitis B. J Gastroenterol Hepatol 2002;17 (Suppl 3):S338-41.

37. Nguyen MH, Keeffe EB. Screening for hepatocellular carcinoma. J Clin Gastroenterol 2002;35(5 Suppl 2):S86-91. 


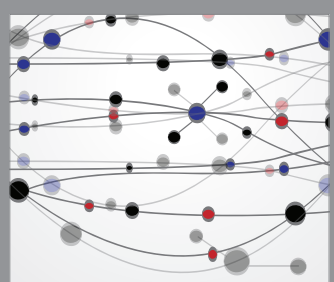

The Scientific World Journal
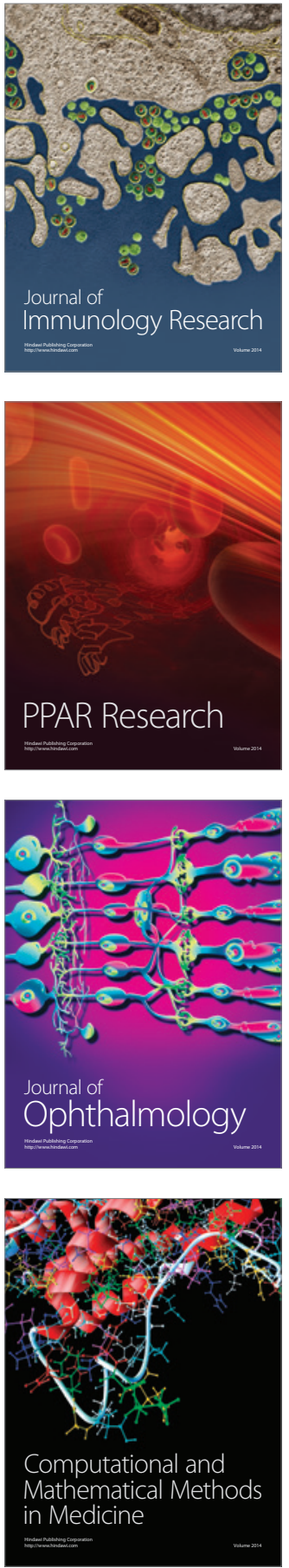

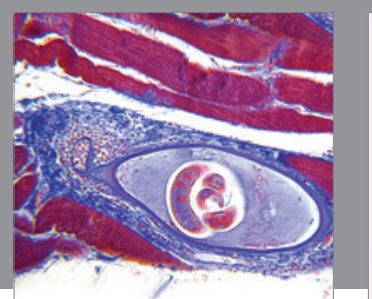

Gastroenterology Research and Practice

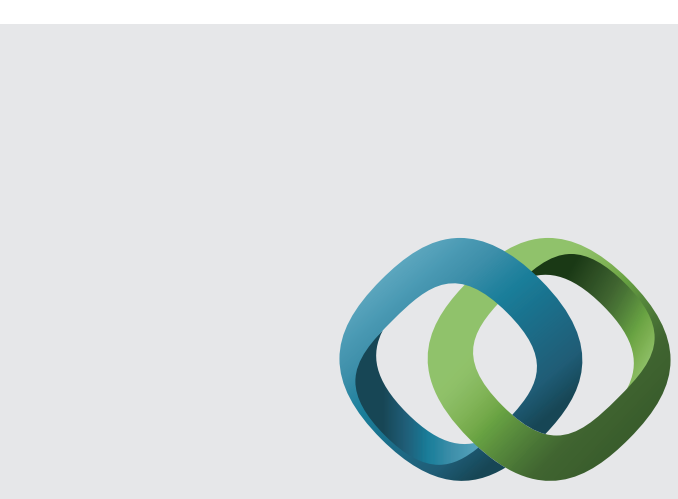

\section{Hindawi}

Submit your manuscripts at

http://www.hindawi.com
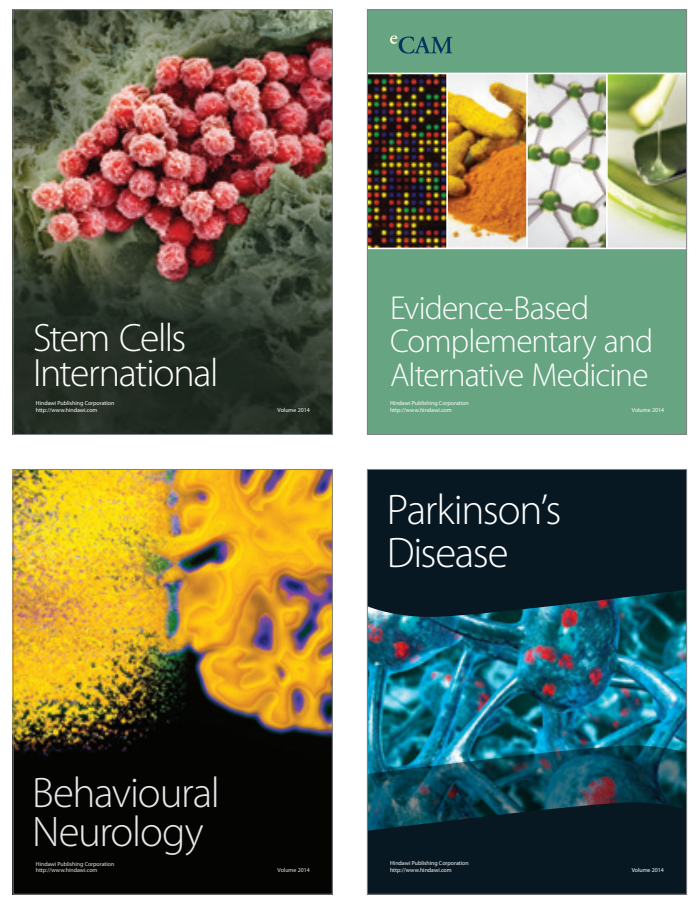
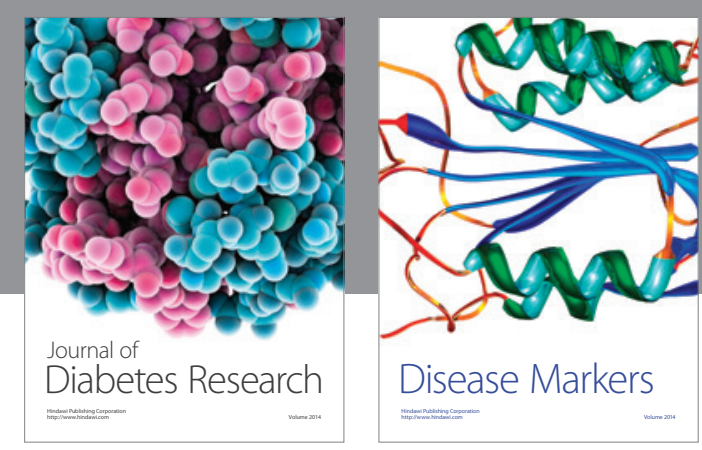

Disease Markers
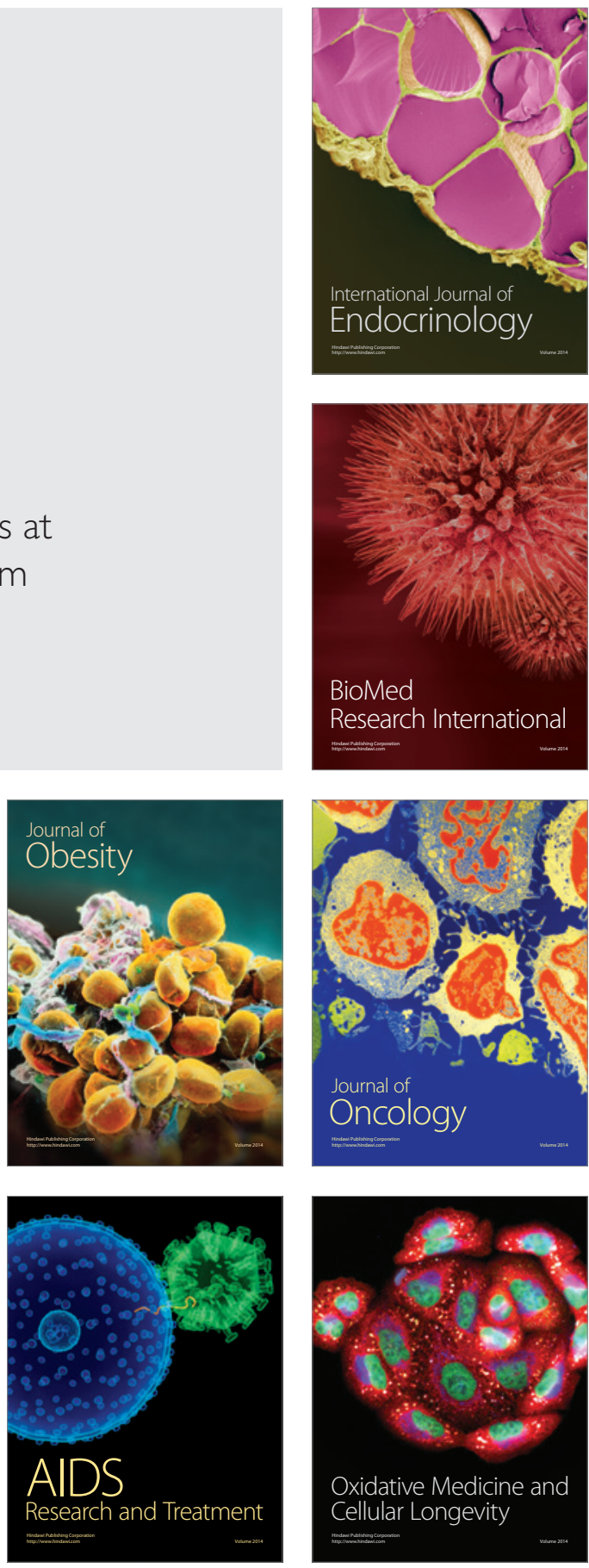